\title{
Segmentasi konsumen pada pasar online di indonesia
}

\author{
Lailatul Hijrah \\ Program Studi Administrasi Bisnis \\ Fakultas Ilmu Sosial dan Politik Universitas Mulawarman, Samarinda \\ Email: lailatul.hijrah1984@gmail.com
}

\begin{abstract}
Abstrak
Penelitian ini bertujuan untuk menganalisis analisis pasar segmentasi konsumen online berbasis online, profil dan karakteristiknya. Pada tahap pertama penelitian ini dilakukan survei yang berkaitan dengan literatur perilaku konsumen Online, kemudian dilakukan analisis cluster dan segmentasi perilaku belanja konsumen Online. Sampel sebanyak 328 responden dikumpulkan melalui survei surat. Untuk melakukan segmentasi sesuai pola pemakaian internet dapat menggunakan metode deskriptif non-overlapping post-hoc, metode ini digunakan untuk mengidentifikasi segmen sesuai dengan pola penggunaan internet. Hasil penelitian menunjukkan bahwa pasar konsumen Online terdiri dari tiga segmen yang umumnya umum digunakan yaitu: Pola segmentasi Dasar Komunikasi, pada segmen konsumen inilah yang menggunakan internet terutama untuk berkomunikasi via e-mail, maka segmen Commerce atau belanja di segmen ini. konsumen yang menggunakan internet untuk berselancar dan melihat-lihat toko online dan segmen ketiga hubungan sosial dan kesenangan, di segmen konsumen inilah yang memanfaatkan internet menggunakan fitur interaktif untuk berinteraksi dan hiburan dengan cara chatting, ngeblog, video streaming, game, menguntit dan mendownload Keterbatasan meliputi data yang dikumpulkan melalui survei yang informasinya berasal dari internet, sehingga dibutuhkan pandangan pihak lain yang bukan pengguna tapi pengamat bisnis online yang memiliki pendapat lain mengenai segmentasi ini. Nantinya segmentasi ini sebenarnya masih bisa dipecah menjadi beberapa sub segmen, selaku usaha penelitian lanjutan.
\end{abstract}

Kata Kunci: Pola penggunaan internet; segmen; anak-anak online

\section{Consumer segmentation in the online market in Indonesia}

\begin{abstract}
This research aims to analyze market analysis Online based online consumer segmentation, profile and their characteristics. In the first stage of this study conducted a survey related to the Online consumer behavior literature, then perform cluster analysis and segmentation Online consumer spending behavior. A sampel of 328 respondents collected by mail survey. In order to perform segmentation according to usage patterns internet can use descriptive method non-overlapping posthoc, this method is used to identify segments in accordance with the pattern of internet usage. Results showed that the consumer market Online consists of three segments that are generally commonly used are: segmentation pattern Basic Communication, in this segment of consumers who use the Internet primarily to communicate via e-mail, then the segment of Commerce or shopping in this segment of consumers who using the internet to surf and look around online stores and third segments of social relationships and pleasure, in this segment of consumers who exploit the internet using interactive features to interact and entertainment by way of chatting, blogging, video streaming, gaming, stalking and downloading. Limitations include data collected through a survey whose information comes from the Internet, so it takes the views of other parties who are not users but observers Online businesses that have other opinions on this segmentation. Later on this segmentation actually still can be broken down into several sub-segments, as continued research efforts.
\end{abstract}

Keywords: Internet use pattern; segment; online sonsumer 


\section{PENDAHULUAN}

Internet telah mengubah cara pandang manusia dalam 10 tahun terakhir khususnya pada dunia bisnis. Mulai dari mencari ide bisnis, merekrut karyawan, cara berproduksi, cara berjualan, hingga bertransaksi semua tidak lepas dari peran internet. Berbagai penelitian telah melakukan penelitian terkait dengan faktor-faktor yang mengarah pada adopsi dan penggunaan internet secara umum dan untuk kepentingan bisnis khususnya (Chang et al., 2005). Kemudian Rodgers dan Sheldon (2002) menyatakan bahwa empat motivasi yang mendasari dan mendorong penggunaan internet, yakni: pencarian informasi (mencari), komunikasi, eksplorasi, dan upaya memperoleh barang (atau berbelanja). Berbagai hasil Penelitian telah muncul, namun bagaimanapun, hasilnya belum sepenuhnya menyajikan bahwa konsumen mengalokasikan sumber daya mereka sesuai dengan pola tertentu mereka menggunakan internet. Dengan demikian, studi ini mencoba mengkaji bagaimana keragaman konsumen internet terkait dengan pola penggunaan internet dalam upaya untuk meminimalkan "perbedaan antara perkembangan akademik dan praktek dunia nyata" pada bahasan khusus yakni segmentasi pasar dengan menggunakan pendekatan consumer-revealed (Wind, 1978:317).

Segmentasi konsumen dapat digunakan untuk mengidentifikasi kelompok pelanggan secara alami dan manfaat lainnya adalah untuk memahami motif masing-masing segmen, karakteristik, dan kebutuhan (Swinyard, 1996). Informasi semacam ini memungkinkan perusahaan untuk memperoleh manfaat strategis atas pesaing mereka, dengan cara membantu mereka untuk mengidentifikasi sikap dan kebutuhan segmen yang berbeda dan unik, dengan demikian informasi ini dapat digunakan untuk mengembangkan peluang strategis yang dapat ditindaklanjuti (Dibb et al., 2002).

Tujuan dari studi ini adalah mengidentifikasi segmentasi konsumen online, profile dan karakteristik mereka. Upaya untuk mempelajari pasar online sesuai dengan pola penggunaan internet konsumennya merupakan sebuah pendekatan yang penting dalam melakukan riset pemasaran - khususnya dengan pendekatan fungsionalisme. Menurut pendekatan ini, arti dan kebutuhan untuk melakukan perilaku tertentu dapat dikenali hanya dengan mengacu pada fungsi utamanya atau manfaat yang diberikan untuk konsumen (Snyder dan Cantor, 1998).

Penelitian ini merujuk pada penelitian Aljukhadar dan Senecal (2011) yang mengidentifikasi segmentasi konsumen online, profile dan karakteristiknya di Kanada, temuan Aljukhadar dan Senecal (2011) menyatakan bahwa konsumen online membentuk tiga segmen global: komunikator dasar (konsumen yang menggunakan internet terutama untuk berkomunikasi melalui e-mail), pembeli eksploratif (konsumen yang menggunakan internet untuk menjelajahi toko Online namun tidak berbelanja), dan sosial thrivers (konsumen yang mengeksploitasi fitur interaktif internet untuk berinteraksi sosial dengan cara chatting, blogging, video streaming, dan men-download). Segmentasi seperti ini membuka wawasan praktisi dari sisi mana segmentasi pasarnya.

Kontribusi penelitian ini diharapkan bermanfaat bagi perusahaan, perusahaan yang berencana untuk mengadopsi pendekatan berbasis sumber daya dapat mempertimbangkan karakteristik segmen pasar secara online ini dalam upaya membuat alokasi anggaran optimal bagi biaya pemasaran. Studi ini dibagi menjadi bagian berikut. Bagian pertama mengulas literatur segmentasi konsumen online dan penggunaan internet. Kemudian, bagian Metode mengandung rincian tentang pengumpulan dan analisis data. Kemudian disajikan berbagai temuan, bersama dengan implikasi penelitian.

\section{TINJAUAN PUSTAKA}

Internet telah merambah berbagai segi kehidupan manusia. Manusia sebagai subjek internet tentu memiliki berbagai prilaku dan hal itu mengikuti psikologi dan kepribadian masing-masing individu manusia. Karakteristik psikologis dan kepribadian dapat diharapkan berdampak pada penggunaan internet masa kini terkait dengan berbagai prilaku yang mereka lakukan. Penelitian Mc.Elroy et al. (2007) menunjukkan bahwa perbedaan pribadi menjadi topik yang cukup menarik untuk mempelajari adopsi individu sebagai konsumen dari berbagai penggunaan situs internet. Selain itu, "motivasi bersosialisasi" seorang user atau konsumen (tercermin oleh beberapa hal seperti ungkapan "saya ingin mengunjungi teman-teman saya" dan ungkapan "saya mau ngobrol dengan teman-teman saya") dikatakan berdampak terhadap upaya penggunaan internet dan meningkatkan motivasi bersosial (Korgaonkar dan Wolin, 1999). 
Kecenderungan meningkatnya suatu kepercayaan juga berdampak untuk meningkatkan penggunaan internet (Gefen, 2000), artinya dalam upaya meningkatkan kepercayaan terhadap sesuatu hal. Seperti studi Kwak et al. (2002) telah mempelajari empat domain yang akan memberikan efek bagi upaya pembelian secara Online, antara lain: sikap, demografi, sifat pengalaman, dan kepribadian. Mereka menemukan bahwa konsumen yang sering mencari informasi produk secara online lebih cenderung yang lebih besar untuk membeli barang. Hung-Pin (2004) menyatakan bahwa persepsi kemudahan penggunaan dan kegunaan mendorong sikap terhadap e-shopping. Lebih lanjut penelitian Siu dan Cheng (2001) menyatakan bahwa sikap terhadap perkembangan teknologi merupakan faktor yang membantu dalam mengidentifikasi potensi pembelian online.

Kemudian Vijayasarathy (2003) meneliti hubungan antara orientasi belanja, jenis produk, dan niat perilaku. orientasi belanja (yang memerlukan kenyamanan, kenikmatan, kebutuhan, dan nilai) dan jenis produk yang terbukti memiliki efek signifikan terhadap niat berbelanja secara online (Vijayasarathy, 2003). Studi Srinivasan et al. (2002) menyatakan bahwa anteseden dan konsekuensi dari loyalitas pelanggan dalam konteks online merupakan faktor-faktor yang secara signifikan mempengaruhi e-loyalty, yang meliputi: kustomisasi, kontak interaktif, komunitas perawatan, kenyamanan, budaya, pilihan, dan karakter. Penelitian menunjukkan bahwa pembeli online yang paling banyak adalah pria muda dengan pengalaman tinggi dalam bidang internet, dengan tingkat pendidikan yang tinggi, dan pendapatan yang lebih tinggi ( $\mathrm{Li}$ et al, 1999;. Sin dan Tse, 2002; Swinyard dan Smith, 2003). Kemudian pada sisi lain konsumen lansia juga termasuk pembeli yang potensial. Walaupun penelitian Sorce et al. (2005) menekankan bahwa pembeli yang lebih tua mencari pada pasar online lebih sedikit frekwensinya dibandingkan dengan pembeli muda.

\section{METODE PENELITIAN}

\section{Pengumpulan Data}

Data yang digunakan adalah para pengguna website di Indonesia. Data penggunaan web dapat dikumpulkan menggunakan ukuran objektif atau subjektif. Ukuran objektif seperti internet navigasi log files dapat digunakan dalam pelacakan navigasi web konsumen untuk memberikan penilaian objektif tentang penggunaan web (Montgomery et al., 2004).

Meskipun demikian, beberapa alasan sehingga membuat peneliti menggunakan cara sendiri dalam rangka melacak frekwensi penggunaan internet, alasan tersebut antara lain: pertama, dengan cara menginvestigasi penggunaan e-mail konsumen selain browsing dan beberapa kegunaan lain yang tidak dapat dilacak menggunakan log files. Kedua, penggunaan log files atau clickstreams data yang disediakan oleh providing yang menyediakan gambaran lengkap untuk pola penggunaan web oleh user. Hal ini karena pengguna bisa mengirim e-mail, berselancar internet, atau men-download file dari rumah, kantor, atau tempat lain dengan koneksi internet. Ketiga, penggunaan log files atau data clickstreams dengan asumsi bahwa koneksi internet yang digunakan oleh satu user - satu partisipan. Namun, dalam kenyataannya, koneksi internet dapat digunakan oleh beberapa individu di rumah tangga, teman-teman, dan pengunjung.

Keempat, penggunaan ukuran objektif seperti log files dan clickstreams tidak akurat dalam mengukur frekuensi penggunaan web karena adanya gangguan noise yang menyertai data yang dihasilkan. Misalnya, pengguna secara bersamaan dapat membuka beberapa halaman (e-mail portal, situs e-commerce, situs download musik) sehingga mustahil untuk mengetahui halaman yang dilihat dan apa frekuensi. Atau, pengguna mungkin membuka halaman tertentu dan meninggalkan PC untuk melakukan tugas lain. Akhirnya, pengguna mungkin menyebarkan program untuk secara otomatis memeriksa e-mail atau untuk men-download atau meng-upgrade aplikasi sementara pengguna sedang berada di tempat, saat komputer hidup. Faktor-faktor ini mendorong peneliti untuk percaya bahwa ukuran subjektif dalam bentuk kuesioner yang dilaporkan sendiri adalah alternatif yang paling akurat untuk mencerminkan pola penggunaan web.

\section{Sampel}

Konsumen yang digunakan sebagai partisipan dalam riset ini adalah semua pengguna internat aktif pada smartphone yang dimiliki oleh Peneliti ditambah dengan berbagai kontak dari rekan-rekan peneliti di seluruh Indonesia. Setelah dikumpulkan ada hampir 12.340 kontak yang terkumpul. 
Sampel diseleksi secara dilakukan secara acak menyusul proses pengulangan. Hal ini dilakukan untuk memastikan sampel yang representatif untuk studi ini. Artinya, bagian dari sampel yang dipilih secara acak telah dihapus dan diganti dengan satu set baru yang dipilih secara acak, setiap kali sampel yang dipilih secara acak menunjukkan bias yang tinggi untuk kelompok konsumen tertentu. Sampel dianggap representatif, ketika daftar e-mail yang digunakan adalah email aktif, yang digunakan untuk mengirim instrumen untuk berpartisipasi dalam penelitian ini.

Undangan e-mail telah dikirim ke sekitar 2.450 konsumen yang dipilih secara acak. Masuknya informasi dari sampel partisipan ditutup ketika sampel kuota tercapai. Dengan demikian, berdasarkan hasil survey total 328 respon digunakan dalam analisis setelah dilakukan penyaringan. Peserta yang menyanggupi dan menanggapi undangan e-mail diminta untuk menjawab survei online. Berikut ini informasi tentang sampel: 67,6 persen perempuan, kemudian 53,3 persen mulai menggunakan internet lebih dari sepuluh tahun yang lalu dan 37,4 persen dalam waktu lima sampai sepuluh tahun. Kemudian statistik usia responden didistribusikan sebagai berikut: 46,7 persen berusia 35 tahun ke bawah, 38,32 persen berusia 35-55 tahun, dan sisanya berusia 56 tahun atau lebih. Dari segi pendidikan sementara 19,65 persen dari peserta telah menyelesaikan sekolah, sisanya sedang menempuh pendidikan tinggi. Penghasilan didistribusikan sebagai berikut: 53,3 persen berpenghasilan Rp 2 juta atau kurang, 24,5 persen berpenghasilan Rp2-7 juta, dan sisanya berpenghasilan di atas Rp 7jt. Jumlah rata-rata item yang dibeli secara online selama 12 bulan terakhir adalah 3,23 item (35,45 persen dari sampel dinyatakan tidak membeli barang apapun secara online selama periode ini).

\section{Pengukuran}

Untuk menggambarkan pola penggunaan internet dari para user, peserta diminta untuk membuat rentang pendapat 100 poin penggunaan utama internet (e-mail, browsing umum, belanja, blogging, chatting, video streaming, men-download, dan stalking) (Rodgers dan Sheldon, 2002). Dengan demikian, basis segmentasi yang digunakan dalam penelitian ini dapat dianggap sebagai segmentasi basis produk-spesifik (Wedel dan Kamakura, 2000).

Awalnya peneliti menerima 347 respon, jawaban yang tidak lengkap dan tidak memadai dikeluarkan; sehingga hanya tersisa 328 responden yang digunakan dalam analisis. Pengalaman dengan internet diukur dengan menggunakan item ( "Berapa tahun Anda telah menggunakan internet"). Persepsi internet self-efficacy diukur dengan item ( "Bagaimana Anda menilai keahlian Anda sebagai konsumen internet? Novice ${ }^{1}$, menengah, atau ahli"). Pengalaman pembelian diukur dengan menggunakan item ( "berapa kali Anda membeli item online selama 12 bulan terakhir"). Item lain yang digunakan untuk mengukur demografi konsumen dan kecepatan koneksi internet (dial-up, $D S L$, atau broadband).

Survei ini menggunakan skala pengukuran yang diadaptasi dari literatur yang merefleksikan beberapa karakteristik psikologis konsumen: (seperti: 12 item dari McKnight et al. (2002)) kecenderungan untuk percaya, kecenderungan untuk percaya pada teknologi baru (dua item dari Kyung dan Bipin (2004); kemudian "orang harus sangat berhati-hati ketika menggunakan teknologi baru", "yang terbaik adalah untuk menghindari menggunakan teknologi baru untuk transaksi finansial bila memungkinkan"), kebutuhan untuk kognisi (tiga item dari Cacioppo dan Petty (1982)). Nilai Alpha Cronbach lebih besar dari 0,90, kecuali untuk konstruk kebutuhan kognisi yang memiliki alpha 0,82 .

\section{HASIL DAN PEMBAHASAN}

Bagian pertama dari hasil penelitian ini adalah memetakan proporsi penggunaan internet menurut peruntukannya dari sampel atau partisipan yang telah mengisi kuesioner kemudian disertai pula dengan berapa konsumsi waktu yang dibutuhkan dalam seminggu menggunakan internet rata-rata sampel. 
Tabel 1. Proporsi Penggunaan Internet dan Konsumsi Waktu

\begin{tabular}{|c|c|c|}
\hline & $\begin{array}{c}\text { Proporsi } \\
\text { Penggunaan }(\%)\end{array}$ & $\begin{array}{c}\text { Waktu dalam } \\
\text { seminggu (jam) }\end{array}$ \\
\hline Email & 35,43 & 2,43 \\
\hline Browsing & 13,43 & 4,32 \\
\hline Shopping & 8,31 & 1,21 \\
\hline Blogging & 2,39 & 0,24 \\
\hline Chatting & 12,43 & 2,32 \\
\hline Video Streaming & 7,65 & 0,92 \\
\hline Stalking & 12,13 & 3,47 \\
\hline Downloading & 2,34 & 1,23 \\
\hline Gaming & 5,89 & 1,58 \\
\hline
\end{tabular}

Kemudian dari proporsi penggunaan tersebut (tabel 1) dilakukan analisis korelasi bivariate antar penggunaan. Hasil berikut (tabel 2) mengindikasikan adanya korelasi positif dan negatif antara jenis penggunaan internet. Banyak pernyataan penting muncul dari adanya tabel 2 ini. Pertama, hubungan negatif antara penggunaan e-mail dengan penggunaan internet yang lain (segmen) menunjukkan bahwa penggunaan tinggi dari e-mail berarti mengurangi menggunakan web untuk tujuan lain dan bahwa sebagian besar peserta menggunakan internet terutama untuk pesan e-mail. Selain itu, hubungan positif antara online chatting dengan belanja online dan hubungan negatif dengan browsing menarik untuk dilihat. Artinya, konsumen yang menggunakan web untuk mengobrol seiring untuk belanja, karena biasanya terkait dengan negosiasi harga ataupun pertanyaan spek barang dan beda dengan browsing umumnya jika sedang chatting akan meninggalkan browsing. Di sisi lain, hubungan positif antara chatting dengan video streaming dan download menunjukkan bahwa konsumen yang chatting online lebih intens untuk menggunakan web untuk menonton video dan men-download musik dan aplikasi lainnya.

Tabel 2. Korelasi Bivariat antara Penggunaan Internet

\begin{tabular}{lccccccccc}
\hline & Email & $\begin{array}{l}\text { Brow- } \\
\text { sing }\end{array}$ & $\begin{array}{l}\text { Shop- } \\
\text { ping }\end{array}$ & $\begin{array}{l}\text { Blog- } \\
\text { ging }\end{array}$ & $\begin{array}{l}\text { Chat- } \\
\text { ting }\end{array}$ & $\begin{array}{l}\text { Video } \\
\text { Streaming }\end{array}$ & $\begin{array}{l}\text { Stalk- } \\
\text { ing }\end{array}$ & $\begin{array}{l}\text { Down- } \\
\text { loading }\end{array}$ ing \\
\hline Email & 1 & & & & & & & & \\
Browsing & $-0,021$ & 1 & & & & & & \\
Shopping & $-0,132$ & 0,102 & 1 & & & & & \\
Blogging & $-0,093$ & 0,127 & $-0,131$ & 1 & & & & \\
Chatting & $-0,218$ & - & 0,324 & 0,003 & 1 & & & \\
& & 0,116 & & & & & & \\
Streaming & $-0,302$ & - & 0,087 & $-0,113$ & 0,324 & 1 & & \\
& & 0,213 & & & & & & \\
Stalking & $-0,437$ & 0,114 & $-0,213$ & $-0,309$ & 0,129 & $-0,116$ & 1 & \\
Downloading & $-0,028$ & 0,213 & $-0,121$ & $-0,078$ & 0,102 & 0,116 & - & 1 \\
& & & & & & & 0,211 & & \\
Gaming & $-0,328$ & - & $-0,097$ & $-0,032$ & - & $-0,118$ & - & 0,112 & 1 \\
& & 0,181 & & & 0,218 & & 0,154 & & \\
\hline
\end{tabular}

Dalam rangka melakukan segmentasi sesuai dengan pola penggunaan internat dapat menggunakan metode deskriptif nonoverlapping post-hoc yang dikembangkan Wedel dan Kamakura (2000). Metode deskriptif non-overlapping post-hoc digunakan untuk mengidentifikasi segmen sesuai dengan pola penggunaan internet. Oleh karena itu, berdasarkan berbagai penggunaan internet oleh konsumen, setiap konsumen diberikan kesempatan hanya untuk memilih satu kelompok homogen tunggal. Penelitian ini melakukan analisis klaster dua langkah, dengan menggunakan software SPSS, untuk segmen konsumen sesuai dengan pola penggunaan internet (yaitu sesuai dengan sembilan internet menggunakan diukur di atas).

Teknik ini cukup untuk sampel yang lebih besar dan dalam situasi di mana peneliti tidak dapat memperkirakan jumlah segmen yang bersifat apriori. Fitur pengelompokan secara otomatis 
menggunakan SPSS, yang mengakibatkan pembagian pada tiga segmen yang berbeda (Tabel 3 menunjukkan Akaike Information Criteria (AIC)). Berikutnya disajikan Distribusi dari konsumen online di antara segmen (Tabel 4). Yang penting, tiga segmen memberikan ringkasan dengan menunjukkan indikasi dan signifikan, perbedaan yang berarti pada variabel segmentasi - pola penggunaan internet.

Tabel 3. Hasil analisis Auto Cluster

\begin{tabular}{ccccc}
\hline Nomor Klaster & AIC & AIC Change & $\begin{array}{l}\text { Ratio of AIC }_{\text {Change }^{\mathrm{b}}} \\
\text { (1875,65 }\end{array}$ & $\begin{array}{l}\text { Ratio of distance } \\
\text { measures }^{\mathrm{c}}\end{array}$ \\
\hline 2 & 1658,54 & $-316,56$ & 1,000 & 1,342 \\
3 & 1434,77 & $-232,11$ & 0,623 & 1,876 \\
4 & 1267,45 & $-121,23$ & 0,321 & 1,078 \\
5 & 1178,94 & $-89,42$ & 0,217 & 1,312 \\
\hline
\end{tabular}

Notes: ${ }^{a}$ The changes are from the previous number of clusters in the table; ${ }^{b}$ the ratios of changes are relative to the change for the two cluster solution; ${ }^{\mathrm{c}}$ the ratios of distance measures are based on the current number of clusters against the previous number of clusters

Dengan menggunakan segment membership sebagai variabel independen, studi ini kemudian melakukan uji Chi-Square $\left(\mathrm{X}^{2}\right)$ dan uji ANOVA untuk menunjukkan perbedaan potensial dalam pengalaman dan demografi dari segmen yang ada. Hasil Analisis (dirangkum dalam Tabel 5) yang menggambarkan bahwa segmentasi menunjukkan bahwa secara signifikan adanya perbedaan antara pengalaman dan demografi. Jenis kelamin, usia, pendapatan, dan tingkat pendidikan yang merupakan variabel demografis yang secara signifikan berbeda-beda tiap segmen (Tabel 5).

Tabel 4. Distribusi Segmen

\begin{tabular}{lcc}
\hline & $\mathrm{n}$ & Persentase Total \\
\hline Komunikasi Dasar & 123 & 37,50 \\
Perdagangan & 113 & 34,45 \\
Hubungan Sosial dan Kesenangan & 92 & 28,05 \\
& 328 & 100 \\
\hline
\end{tabular}

Tabel 5. Profile Faktor dengan Distribusi Signifikansi antar segmen

\begin{tabular}{lccc}
\hline & $\begin{array}{c}\text { Komunikasi } \\
\text { Dasar }\end{array}$ & Perdagangan & $\begin{array}{c}\text { Hubungan Sosial } \\
\text { dan Kesenangan }\end{array}$ \\
\hline Gender (\% Wanita)** & 68 & 53,2 & 73,3 \\
Pendidikan* & 12,2 & 11,9 & 32,3 \\
SMA kebawah & 87,8 & 88,1 & 67,7 \\
Akademi ke atas & & & \\
Usia* & 48,3 & 46,1 & 53,4 \\
Muda (<35 tahun \%) & 46,3 & 32,4 & 37,3 \\
Pertengahan (35-54 th \%) & 5,4 & 21,5 & 9,3 \\
Usia Tua (>54 \%) & & & 53,3 \\
Pendapatan* & 35,4 & 38,7 & 42,1 \\
Rp2 jt ke bawah & 36,1 & 44,5 & 4,6 \\
Rp2 jt - Rp7 jt & 28,5 & 16,8 & 6,9 \\
Diatas Rp7 jt & & & 67,3 \\
Persepsi self-eficacy internet** & 4,5 & 5,3 & 25,8 \\
Novice & 78,3 & 72,8 & 3,2 \\
Sedang & 17,2 & 21,9 & 23,3 \\
Ahli & 2,7 & 5 & \\
Jumlah produk yang dibeli tahun lalu* & 11,3 & 17,2 & \\
Frekwensi Penggunaan Internet* & & & \\
& & & \\
\hline
\end{tabular}


Kecepatan Koneksi Internet**

$\begin{array}{lccc}\text { Dial-up (\%) } & 0,2 & 0,12 & 0,17 \\ \text { DSL (\%) } & 24,4 & 17,2 & 12,1 \\ \text { Broadband (\%) } & 75,4 & 82,68 & 87,73\end{array}$

Notes: Sig pada $* \mathrm{p}<0,05$ dan $* * \mathrm{p}<0,01$ : hanya faktor yang memiliki distribusi signifikan di antara cluster yang ditampilkan

Selain itu, persepsi self-eficacy internet, frekuensi penggunaan internet (jam per minggu), dan kecepatan koneksi internet secara bervariasi berbeda signifikan antara segmentasi (Tabel 5). Selanjutnya, rata-rata jumlah produk segmen kedua (segmen: perdagangan) dilaporkan membeli secara online selama 12 bulan terakhir adalah secara signifikan lebih tinggi dari jumlah produk yang dilaporkan oleh dua segmen lainnya $(\mathrm{p}=0,003)$. Sebagai tambahan, faktor disposisional (kecenderungan untuk percaya, kecenderungan untuk percaya teknologi baru, dan kebutuhan kognisi) tidak secara signifikan berbeda antara segmentasi (semua p ini berada pada taraf 0,31 tidak signifikan).

\section{Pembahasan}

Penelitian ini menganalisis segmentasi pada pasar online dengan menggunakan data persepsi konsumen. Hasil penelitian menunjukkan bahwa, menurut pola penggunaan internet, pasar konsumen online terdiri dari tiga segmentasi umum, antara lain: Komunikasi Dasar (konsumen yang menggunakan internet terutama untuk berkomunikasi melalui e-mail), Perdagangan atau belanja (konsumen yang menggunakan internet untuk berselancar dan melihat-lihat toko online), dan hubungan sosial dan kesenangan (konsumen yang mengeksploitasi internet dengan menggunakan fitur interaktif untuk berinteraksi dan hiburan dengan cara chatting, blogging, video streaming, gaming, stalking dan download). Studi lanjutnya yaitu mencoba mengungkapkan profile untuk masing-masing segmentasi berdasarkan faktor-faktor demografi dan pengalaman (Tabel 5).

Pada segmen pertama yaitu Komunikasi dasar sebagian responden adalah perempuan (68 persen) dan berpendidikan tinggi (87,8 persen) yang secara dominan pada kelompok umur muda dan pertengahan, serta homogen seluruh golongan pendapatan. Mereka cenderung memiliki internet persepsi self-eficacy rata-rata dan mereka menggunakan internet lebih jarang (11,3 jam per minggu) dari konsumen lain. Segmen Komunikasi dasar memiliki kecepatan koneksi internet yang menengah ke atas (DSL dan Broadband) walaupun lebih rendah dibandingkan dengan segmen lainnya. Kemudian segmen perdagangan atau bisnis memiliki dominasi pada pendidikan tinggi (88,1 persen), laki-laki atau perempuan hampir seimbang walau perempuan lebih tinggi, dan terutama untuk kelompok usia yang pertengahan ke bawah. Segmentasi ini, memiliki rata-rata keahlian internet yang menengah ke atas dengan pendapatan tertinggi lebih dari komunikasi dasar dan interaksi sosial. Konsumen membentuk segmen perdagangan memiliki kecepatan koneksi internet yang tinggi (DSL atau broadband) dan secara signifikan menghabiskan lebih banyak waktu (17,2 jam per minggu) dari komunikasi dasar tetapi kurang dari segmentasi interaksi sosial.

Segmentasi interaksi sosial dan kesenangan umumnya milik kelompok usia termuda (kurang dari 35 tahun) dan secara dominan ada pada level pendapatan terendah lebih dari komunikasi dasar dan perdagangan. Selain itu, segmen interaksi sosial cenderung memiliki keahlian internet sedang dan tinggi dan menghabiskan lebih banyak waktu di internet (23,3 jam per minggu) dibandingkan dengan komunikasi dasar dan perdagangan. Meskipun banyak orang yang masuk dalam segmen ini termasuk ke dalam golongan berpenghasilan rendah, namun interaksi sosial menggunakan kecepatan koneksi internet yang tinggi (koneksi broadband).

Penelitian ini berimplikasi terhadap pengembangan teori terkait dengan segmentasi pasar Online yang memfokuskan pada konsumen Online shopping seperti didukung dengan berbagai penelitian lainnya (Mathwick, 2001; Swinyard dan Smith, 2003; Allred et al., 2006; Kau et al., 2003; Barnes et al., 2007; Jayawardhena et al., 2007). Hasil temuan menunjukkan dasar segmentasi ini sangat baik dan berguna karena jelas menggambarkan tiga kelompok konsumen yang heterogen dengan pola yang berbeda dari penggunaan internet. Studi ini didukung oleh studi Wedel dan Kamakura (2000) yang mengevaluasi beberapa dasar segmentasi dan menemukan bahwa untuk memenuhi kriteria yang memuaskan dari sebuah pangsa pasar Online maka dibutuhkan segmentasi yang efektif. 
Perusahaan atau praktisi bisnis yang berupaya untuk mengikuti pendekatan pemasaran berbasis sumber daya untuk alokasi optimal anggaran pemasaran harus mempertimbangkan karakteristik dari segmen pasar Online ini. Misalnya, menurut hasil temuan, iklan menargetkan pembeli lebih banyak, sehingga menentukan space iklan yang terbaik dihabiskan di situs tertentu (misalnya portal berita, mesin pencari dan lain sebagainya) daripada di situs sosial (misalnya chatting dan situs videosharing). Atau, promosi yang menargetkan segmen yang lebih muda (misalnya interaksi sosial) dapat secara efektif mempertimbangkan situs web sosial (misalnya chatting blogging dan media sosial lainnya) dan situs web interaktif (video streaming, aplikasi download musik dan video). Khususnya, segmen komunikasi dasar - dapat dicapai terutama dengan menggunakan iklan e-mail (iklan misalnya e-mail pemasaran, iklan generik pada portal e-mail).

Penelitian Aljukhadar dan Senecal (2011) sebagai rujukan utama penelitian ini memiliki temuan yang berbeda dalam hal klasifikasi penggunaan internet, penelitian ini memiliki sembilan, sementara Aljukhadar dan Senecal (2011) memilki tujuh klasifikasi penggunaan internet, namun dalam hal korelasi dan hasil temuan menggunakan metode deskriptif non-overlapping post-hoc sejalan dengan penelitian Aljukhadar dan Senecal (2011).

\section{SIMPULAN}

Sebagaimana telah dikemukakan di atas bahwa tujuan Penelitian ini adalah dalam upaya memetakan segmen para pengguna internet dalam rangka memilih pangsa pasar yang efektif bagi para praktisi dalam memilih segmen konsumennya dalam sistem belanja Online. Menurut pola penggunaan internet, pasar konsumen online terdiri dari tiga segmentasi yang secara umum sering digunakan yaitu: segmentasi pada pola Komunikasi Dasar, dalam segmen ini konsumen yang menggunakan internet terutama untuk berkomunikasi melalui e-mail, kemudian segmen Perdagangan atau belanja, dalam segmen ini konsumen yang menggunakan internet untuk berselancar dan melihat-lihat toko online dan ketiga segmen hubungan sosial dan kesenangan, dalam segmen ini konsumen yang mengeksploitasi internet dengan menggunakan fitur interaktif untuk berinteraksi dan hiburan dengan cara chatting, blogging, video streaming, gaming, stalking dan download.

Walau telah memberikan kontribusi bagi para kontribusi, namun penelitian ini memiliki beberapa keterbatasan antara lain data yang dikumpulkan melalui survei yang informasinya berasal dari pengguna internet, sehingga dibutuhkan pandangan dari pihak lain yang bukan pengguna tapi pemerhati sebagai pihak III yang memiliki opini lain tentang segmentasi seperti ini. Kemudian dari segmentasi ini sebenarnya masih bisa dipecah dalam beberapa sub-segmen, sebagai upaya penelitian lanjutan.

\section{DAFTAR PUSTAKA}

Aljukhadar, M dan Senecal S. (2011) Segmenting the online konsumer Market. Marketing Intelligence \& Planning, Vol. 29 No. 4, 2011 pp. 421-435

Allred, C., Smith, S.M. and Swinyard, W.R. (2006), "Shopping lovers and fearful conservatives: a market segmentation analysis", International Journal of Retail \& Distribution Management, Vol. 34 Nos 4/5, pp. 308-34.

Barnes, S.J., Bauer, H.H., Neumann, M.M. and Huber, F. (2007), "Segmenting cyberspace: a customer typology for the internet", European Journal of Marketing, Vol. 41 Nos 1/2, pp. 71-93.

Cacioppo, J. and Petty, R. (1982), "The need for cognition", Journal of Personality and Social Psychology, Vol. 42 No. 1, pp. 116-31.

Chang, M.K., Cheung, W. and Lai, V.S. (2005), "Literature derived reference models for the adoption of online shopping", Information \& Management, Vol. 42 No. 4, pp. 543-59.

Dibb, S., Stern, P. and Wensley, R. (2002), "Marketing knowledge and the value of segmentation", Marketing Intelligence \& Planning, Vol. 20 No. 2, pp. 113-19.

Gefen, D. and Straub, D. (1997), "Gender differences in perception and adoption of e-mail: an extension to the technology acceptance model", Management Information Systems Quarterly, Vol. 21 No. 4, pp. 389-400. 
Hung-Pin, S. (2004), "An empirical study on predicting consumer acceptance of e-shopping on the web", Information \& Management, Vol. 41 No. 3, pp. 351-69.

Jayawardhena, C., Wright, L.T. and Dennis, C. (2007), "Consumers online: intentions, orientations and segmentation", International Journal of Retail \& Distribution Management, Vol. 35 No. 6 , pp. 515-26.

Korgaonkar, P. and Wolin, L. (1999), "A multivariate analysis of web usage”, Journal of Advertising Research, Vol. 39 No. 2, pp. 53-68.

Kwak, H., Fox, R.J. and Zinkhan, G.M. (2002), "What products can be successfully promoted and sold via the internet?", Journal of Advertising Research, Vol. 42 No. 1, pp. 23-38.

Kyung, K.K. and Bipin, P. (2004), "Initial trust and the adoption of B2C e-commerce: the case of internet banking", Database for Advances in Information Systems, Vol. 35 No. 2, pp. 50-65.

Li, H., Kuo, C. and Russell, M.G. (1999), "The impact of perceived channel utilities, shopping orientations, and demographics on the consumer's online buying behavior", Journal of Computer Mediated Communication, Vol. 5 No. 2, p. 36.

Mathwick, C. (2001), "Understanding the online consumer: a typology of online relational norms and behavior", Journal of Interactive Marketing, Vol. 16 No. 1, pp. 40-55.

McElroy, J.C., Hendrickson, A., Townsend, A. and DeMarie, S. (2007), "Dispositional factors in internet use: personality versus cognitive style", Management Information Systems Quarterly, Vol. 31 No. 4, pp. 809-20.

Montgomery, A.L., Li, S., Srinivasan, K. and Liechty, J.C. (2004), "Modeling online browsing and path analysis using clickstream data", Marketing Science, Vol. 23 No. 4, pp. 579-95.

Rodgers, S. and Sheldon, K.M. (2002), "An improved way to characterize internet consumers", Journal of Advertising Research, Vol. 42 No. 5, pp. 85-94.

Sin, L. and Tse, A. (2002), "Profiling internet shoppers in Hong Kong: demographic, psychographic, attitudinal and experiential factors", Journal of International Consumer Marketing, Vol. 15 No. 1, pp. 7-30.

Siu, N.Y. and Cheng, M.M. (2001), "A study of the expected adoption of online shopping: the case of Hong Kong”, Journal of International Consumer Marketing, Vol. 13 No. 3, pp. 87-106.

Snyder, M. and Cantor, N. (1998), "Understanding personality and social behavior: a functionalist strategy", in Gilbert, D.T., Fiske, S.T. and Lindzey, G. (Eds), The Handbook of Social Psychology, Oxford University Press, New York, NY.

Sorce, P., Perotti, V. and Widrick, S. (2005), "Attitude and age differences in online buying", International Journal of Retail \& Distribution Management, Vol. 33 No. 2, pp. 122-33.

Srinivasan, S., Anderson, R. and Ponnavolu, K. (2002), "Consumer loyalty in e-commerce: an exploration of its antecedents and consequences", Journal of Retailing, Vol. 78 No. 1, pp. 41-50.

Swinyard, W.R. (1996), "The hard core and Zen riders of Harley Davidson: a market-driven segmentation analysis", Journal of Targeting, Measurement and Analysis for Marketing, Vol. 4 No. 4, pp. 337-62.

Swinyard, W.R. and Smith, S.M. (2003), "Why people (don't) shop online: a lifestyle study of the internet consumer", Psychology \& Marketing, Vol. 20 No. 7, pp. 567-97.

Vijayasarathy, L.R. (2003), "Shopping orientations, product types and internet shopping intentions", Electronic Markets, Vol. 13 No. 1, pp. 67-80.

Wedel, M. and Steenkamp, J.-B.E.M. (1989), "Fuzzy clusterwise regression approach to benefit segmentation", International Journal of Research in Marketing, Vol. 6, pp. 241-58. 
Wind, Y. (1978), "Issues and advances in segmentation research", Journal of Marketing Research, Vol. 15, pp. 317-37. 